\title{
Technique for posterior segment evaluation in paediatric cases undergoing cataract surgeries
}

\author{
Sudarshan Khokhar, Amber Amar Bhayana ำ , Tavishi Singhal, Mousumi Banerjee
}

Ophthalmology, Dr Rajendra Prasad Centre for Ophthalmic Sciences, All India Institute of Medical Sciences, New Delhi, Delhi, India

\section{Correspondence to}

Dr Amber Amar Bhayana; amber.amar.bhayana@gmail. com

Accepted 18 December 2020

\section{DESCRIPTION}

We have devised a novel technique for intraoperative fundus assessment which we routinely use in our paediatric cataract surgery cases. After the routine steps of paediatric lens aspiration, just before the intraocular lens (IOL) is implanted (or other ways if aphakia is planned for), we insert a 25 -gauge endoilluminator routinely used for vitreoretinal surgeries (commonly involving LED (light-emitting diode) bulbs) ${ }^{1}$ through one of the self-sealing corneal side ports in the bag after filling it with viscoelastic if posterior rhexis is not done and into the anterior vitreous cavity after limited anterior vitrectomy in case posterior capsulorhexis has been done (figure 1). A contact lens for wide-angle viewing is placed on the cornea coupled with viscoelastic. We commonly use MiniQuad lens (Volk Optical), which has a magnification of $0.48 \times$ with a static field of $106^{\circ}$ and a dynamic field of $127^{\circ} .{ }^{1}$ We have Figure 2 shows the posterior segment anomalies detected intraoperatively in four children with total white cataract. All the manoeuvres are done using sterile surgical instruments, minimising the risk of any infection. The endoilluminator and the wideangle viewing lens are sterile and are the same as that normally used during vitrectomy. To date, we have not had any sort of infective inflammation in any of the paediatric cataract surgery eyes in which this posterior segment evaluation technique was
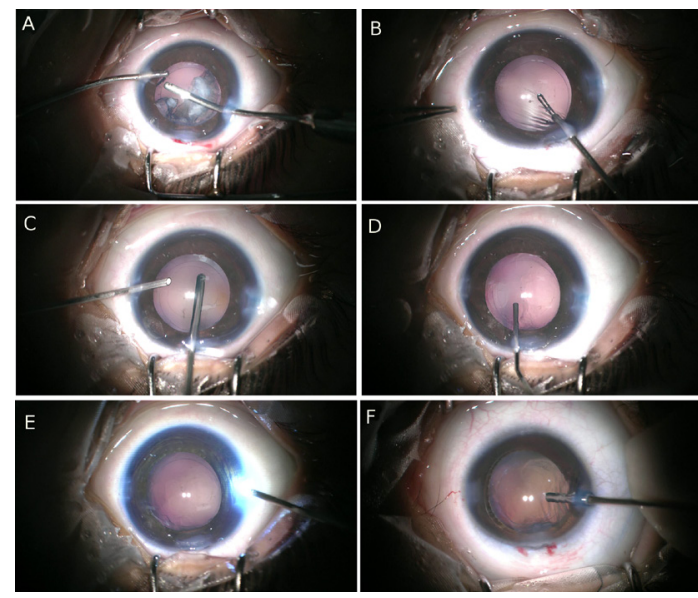

Limited 2021. No commercial re-use. See rights and permissions. Published by BMJ.

\begin{tabular}{l}
\hline To cite: Khokhar S, \\
Bhayana AA, Singhal T, \\
et al. BMJ Case Rep \\
2021;14:e240931. \\
doi:10.1136/bcr-2020- \\
240931 \\
\hline
\end{tabular}

Figure 1 The steps of our technique. (A) Lens aspiration is done with bimanual irrigation and aspiration probes. (B) Posterior curvilinear capsulorhexis is done with 25-gauge intravitreal forceps. (C) Limited anterior vitrectomy is done. (D) Bag filled with viscoelastic. $(E, F)$ 25-gauge illuminator being injected through the side port. recorded numerous posterior segment findings.
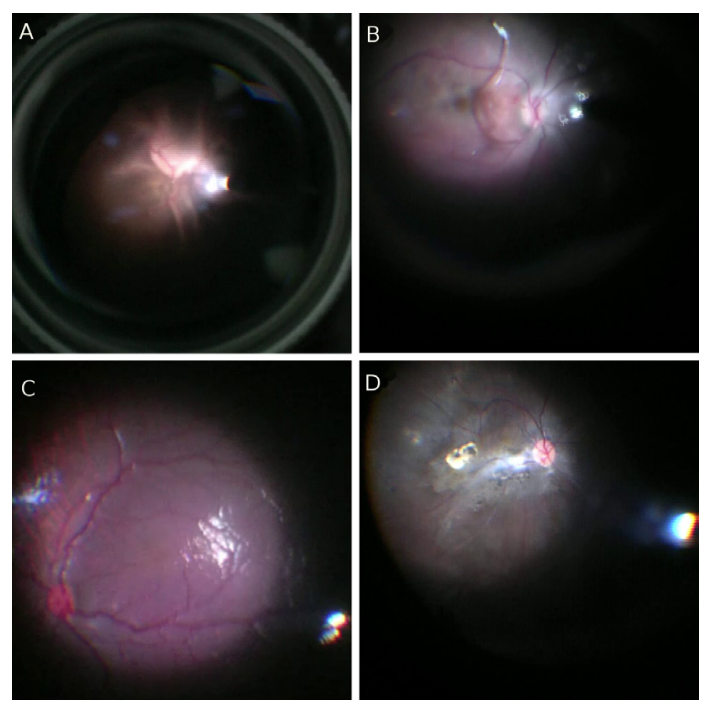

Figure 2 (A) Closed funnel retinal detachment in a 24-month-old child. (B) Vascular stalk of persistent fetal vasculature in an 8-month-old child. (C) Foveal hypoplasia in a case of aniridia in a 30-month-old child. (D) Toxoplasmosis macular scar in a 15-month-old child.

used. IOL is implanted and/or the wound is closed/ sutured normally after viscoaspiration.

Our technique has the advantage of allowing for documentation and teaching and providing a fundus view through a clear media (corneal and vitreous opacities excluded) which cannot be in any way compared with what is visible even through a mildly cataractous lens. It can also prognosticate cases and we know what visual potential to expect postoperatively. Documentation of posterior segment findings usually requires expensive machinery, such as traditional fundus cameras, RetCam and Optos. Our technique is simple and allows recording even in the most basic ophthalmic surgical theatres with an operating microscope, wide-angle lens and a light source. Patient cooperation is not a hindrance and neither are associated involuntary ocular movements like nystagmus. A decent view of the fundus is possible even in poorly dilating pupils because the

Learning points 
source of illumination is in the posterior segment itself. Intraoperative video recordings are routinely practised by posterior segment surgeons, and we have used the same basic principles and modified them a bit to be used as a novel and ergonomic method by anterior segment surgeons during cataract surgeries.

Contributors SK: concept, surgery. AAB: preparation of the manuscript. TS: video editing. MB: editing of the manuscript.

Funding The authors have not declared a specific grant for this research from any funding agency in the public, commercial or not-for-profit sectors.
Competing interests None declared.

Patient consent for publication Parental/guardian consent obtained.

Provenance and peer review Not commissioned; externally peer reviewed.

\section{ORCID iDs}

Amber Amar Bhayana http://orcid.org/0000-0002-0770-601X

Mousumi Banerjee http://orcid.org/0000-0003-4346-246X

\section{REFERENCE}

1 de Oliveira PRC, Berger AR, Chow DR. Vitreoretinal instruments: vitrectomy cutters, endoillumination and wide-angle viewing systems. Int J Retina Vitreous 2016;2:28.

Copyright 2021 BMJ Publishing Group. All rights reserved. For permission to reuse any of this content visit

https://www.bmj.com/company/products-services/rights-and-licensing/permissions/

BMJ Case Report Fellows may re-use this article for personal use and teaching without any further permission.

Become a Fellow of BMJ Case Reports today and you can:

- Submit as many cases as you like

- Enjoy fast sympathetic peer review and rapid publication of accepted articles

- Access all the published articles

- Re-use any of the published material for personal use and teaching without further permission

\section{Customer Service}

If you have any further queries about your subscription, please contact our customer services team on +44 (0) 2071111105 or via email at support@bmj.com.

Visit casereports.bmj.com for more articles like this and to become a Fellow 